\title{
Interdisciplinary Practice Approach to Proteins Study and Analysis in Undergraduate Program in Biotechnology
}

\author{
Xavier, L.P.; McCulloch, J.A.; Santos, A.V. \\ Faculdade de Biotecnologia-ICB/UFPA, Pará-Brasil
}

The undergraduate program in Biotechnology at Federal University of Pará has been consolidated as excellence course in Pará, however there are still difficulties in some practice classes. In this way, the aim of this research was to develop low cost and easy implementation methodologies of teaching and learning that help the students to understand the integration of contents, and promote interdisciplinary and greater integration among professors. The main theme of the study was "Proteins: obtaining to analysis". Professors charged of subjects in Biochemistry, Protein Biochemistry, Protein Engineering, Microbiology and Separation Methods of Biotech Products, has developed this work, which has been promoted by the program PROINT of UFPA. The main purpose of PROINT has been the consolidation of undergraduate teaching projects. Thirty students enrolled in the third semester were involved in this study. To perform the practice classes: a) were made models with alternative materials (Styrofoam, cardboard); b) were used the tutorials and exercises online as a complement to the teaching and learning process and; c) were analyzed chromatograms, simulation purification steps, assembled and interpreted tables purification (falcon tubes, colored beads). Were used also conventional materials and reagents purchased in practices related to microbiology with the support of PROINT. Until now had been a greater interest and participation of students in the implementation of practices and a greater understanding of the theoretical content covered.

Keywords: proteins, interdisciplinary practices, teaching project

Support by PROINT/UFPA 